\title{
A study to use activated sludge anaerobic combining aerobic for treatment of high salt seafood processing wastewater
}

\author{
Thi Thu Hoai Pham ${ }^{a^{*}}$ and Thi Mai Huong Nguyen ${ }^{\mathrm{b}}$
}

${ }^{a}$ Department of Science research, University of Economic and Technical Industries, Vietnam

${ }^{b}$ Department of Food Technology, University of Economic and Technical Industries, Vietnam

\begin{tabular}{l}
\hline C H R O N I C L E \\
\hline Article history: \\
Received August 2, 2019 \\
Received in revised form \\
August 18, 2019 \\
Accepted August 19, 2019 \\
Available online \\
August 19, 2019 \\
\hline Keywords: \\
Seafood processing wastewater \\
Salt concentration \\
Activated sludge \\
Anaerobic \\
Aerobic \\
\end{tabular}

\section{A B S T R A C T}

Seafood processing operations generate a high strength wastewater, which contain organic pollutants in soluble, colloidal, particulate form and salt content, up to $30 \mathrm{~g} \mathrm{NaCl} / \mathrm{L}$. This research aimed to study the effect of salt $(\mathrm{NaCl})$ concentration on the treatment efficiency of seafood processing wastewater by the use of a laboratory-scale bioreactor, which is operated in anaerobic combining aerobic system with concentration salt different from $0-5 \%$. The results showed that the wastewater from seafood processing with the chemical input parameters of $\mathrm{pH}=7-8.5, \mathrm{COD}=2000 \mathrm{mg} / \mathrm{L}$, total nitrate nitrogen $=150 \mathrm{mg} / \mathrm{L}, \mathrm{NH}^{4+}=$ $90 \mathrm{mg} / \mathrm{L}$, total phosphorus $=50 \mathrm{mg} / \mathrm{L}$, salt content $3 \%$ was treated with anaerobic activated sludge content of $8000 \mathrm{mg} / 1,16 \mathrm{HRT}$ and combining an aerobic activated sludge content of $6000 \mathrm{mg} / 1,6 \mathrm{HRT}, \mathrm{DO}=2-4 \mathrm{mgO}_{2} / 1$ with the acclimatization of $7 \%$ bacteria Bacillus velezensis at high salinity The parameters output wastewater was treated according to standards QCVN 11-MT:2015/BTNMT (column B).

\section{Introduction}

Seafood processing operations generate a high strength wastewater, which contain organic pollutants in soluble, colloidal, particulate form and salt content, up to $30 \mathrm{~g} \mathrm{NaCl} / 1$. Saline wastewater are usually treated through physico-chemical means, as conventional biological treatment which is known to be strongly inhibited by salt (mainly $\mathrm{NaCl}$ ). However, physicochemical techniques are energy-consuming and their startup and running costs are high. Nowadays, alternative systems for the removal of organic matter are studied, most of them are involved with anaerobic or aerobic biological treatment ${ }^{1}$. However, biological activities in the activated sludge system are sensitive to environmental factors such as temperature, $\mathrm{pH}$, dissolved oxygen and feed conductivity. The effect of salt on nitrification/denitrification process is a major concern in recent years. Previous studies indicated that high salinity adversely effects the reduction of chemical oxygen demand (COD) in normal wastewater plants of activated sludge $e^{2,3}$. However, the adaptation of biomass to saline wastewater improved COD reduction ${ }^{4,5}$.

* Corresponding author.

E-mail address: ptthoai@uneti.edu.vn (T. T. H. Pham)

(C) 2020 Growing Science Ltd. All rights reserved

doi: $10.5267 /$ j.ccl.2019.8.002 
Past studies with highly saline wastewater from seafood industry and RO or other membrane processes treating wastewater effluent are inadequate to draw any conclusive inference on the treat-ability of saline wastewater. In such water, high levels of nutrients (nitrogen ranging of 50$60 \mathrm{mg} / \mathrm{L}$ and phosphorus ranging10-12 mg/L) are common features. A recent sequential batch reactor (SBR) study concentrated on nutrient reduction from saline wastewater (artificial seafood processing wastewater). The wastewater was prepared to have the approximate concentrations of total COD $1000 \mathrm{mg} / \mathrm{L}$, soluble COD $500 \mathrm{mg} / \mathrm{L}$, TKN $120 \mathrm{mg} / \mathrm{L}$, PO-P $20 \mathrm{mg} / \mathrm{l}^{6}$.

In this study, the wastewater from seafood processing with the chemical input parameters of $\mathrm{pH}$ $=7-8.5, \mathrm{COD}=2000 \mathrm{mg} / \mathrm{L}$, total nitrate nitrogen $=150 \mathrm{mg} / \mathrm{L}, \mathrm{NH} 4+=90 \mathrm{mg} / \mathrm{L}$, total phosphorus $=50 \mathrm{mg} / \mathrm{L}$, salt content $3 \%$ was treated with anaerobic activated sludge by combining an aerobic activated sludge. Biological treatment involves the use of microorganisms to remove dissolved nutrients from a discharge ${ }^{7-9}$. Organic and nitrogenous compounds in the discharge can serve as nutrients for rapid microbial growth under aerobic, anaerobic, or facultative conditions. Biological treatment systems can convert approximately one-third of the colloidal and dissolved organic matter into stable end products and convert the remaining two-thirds into microbial cells that can be removed through gravity separation. The organic load present is incorporated in part as biomass by the microbial populations, and almost all the rest is liberated gas. Carbon dioxide $\left(\mathrm{CO}_{2}\right)$ is produced in aerobic treatments, whereas anaerobic treatments produce both carbon dioxide and methane $\left(\mathrm{CH}_{4}\right)$. In seafoodprocessing wastewaters, the nonbiodegradable portion is very low. The author reported nutrient reduction efficiency over $95 \%$ in sequential bio-reactors with the acclimatization of bacteria Bacillus velezensis at high salinity as reported by others ${ }^{4,5,10}$. The result of parameters output wastewater was treated according to standards QCVN 11-MT:2015/BTNMT (column B).

\section{Results and discussion}

\subsection{Adaptation of activated sludge}

In an activated sludge treatment system, an acclimatized, mixed, biological growth of microorganisms (sludge) interacts with organic materials in the wastewater in the presence of excess dissolved oxygen and nutrients (nitrogen and phosphorus). The microorganisms convert the soluble organic compounds to carbon dioxide and cellular materials. Research results of culture activated sludge and change of biomass content over time are shown in Fig. 1. and Fig. 2

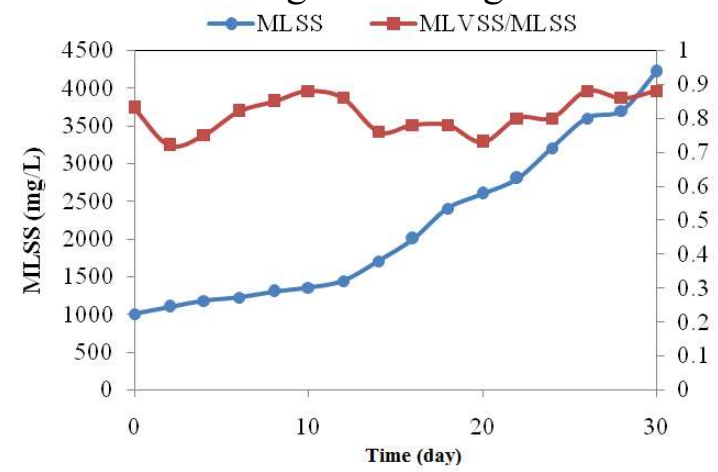

Fig 1. MLSS, MLVSS/MLSS in aerobic tank

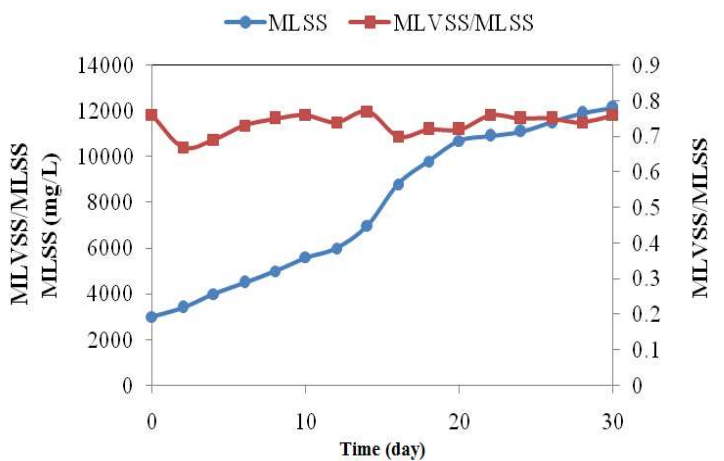

Fig 2. MLSS, MLVSS/MLSS in anerobic tank

Fig. 1 shows the biomass content (MLSS) increased from 1000 to $4215 \mathrm{mg} / \mathrm{L}$ after 30 days of activated sludge culture. At the first stage when starting to operate from day 1 to day 10, the amount of microorganisms in activated sludge is at the stage of adapting to the wastewater environment and the sludge develops slowly. To the growth stage of microorganisms with nutrient-rich seafood processing wastewater, activated sludge is well developed, MLSS increases rapidly from 1350 to $4215 \mathrm{mg}$ / L. MLVSS / MLSS ratio assesses biomass density in activated 
sludge ranging from 0.72 to 0.88 . For normal activated sludge this ratio is usually 0.8 . Thus, the activated sludge used in the study has good adaptation and growth to wastewater.

Fig. 2 shows the initial activated sludge amount was $3000 \mathrm{mg} / \mathrm{L}$, after 30 days of culture, the mud content increased to $12150 \mathrm{mg} / \mathrm{L}$. MLVSS / MLSS ratio ranges from 0.67 to 0.77 , SVI index from 56 to $95 \mathrm{ml} / \mathrm{g}$. Thus, the anaerobic sludge grows well and is of good quality.

\subsection{Effect of salt concentration to efficiency}

Experimental study of the effect of salt content (salinity) on processing efficiency, to survey how much salt content will affect the processing efficiency of the system. Characteristics of seafood processing wastewater used in the experiment with input parameters: $\mathrm{pH}=7-8.5, \mathrm{COD}$ $=2000 \mathrm{mg} / \mathrm{L}$, total nitrate nitrogen $=150 \mathrm{mg} / \mathrm{L}, \mathrm{NH} 4+=90 \mathrm{mg} / \mathrm{L}$, total phosphorus $=50 \mathrm{mg} / \mathrm{L}$.

After the wastewater is treated in anaerobic tank, it will enter the aerobic tank for treatment. During treatment, the activated sludge content and retention time are kept constant. The activated sludge content in anaerobic tank is about $8000 \mathrm{mg} / \mathrm{L}$, the retention time is 16 hours. In aerobic tanks, the activated sludge content is about $6000 \mathrm{mg} / \mathrm{L}$ and the retention time (HRT) is 8 hours, $\mathrm{DO}=2-4 \mathrm{mgO}_{2} / 1$. Result of salt concentration to efficiency at different concentration $(0-6 \% \mathrm{NaCl}$ w/v) ${ }^{11,12}$ is shown in Fig. 3:

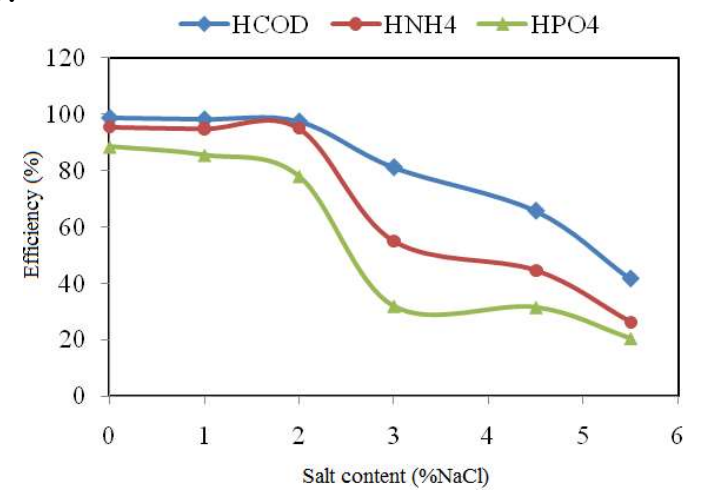

Fig 3. Effect of salt concentration $(\% \mathrm{NaCl})$ to efficiency

In show Fig. 3, we see that salt content affects the efficiency of $\mathrm{COD}, \mathrm{NH}^{4+}$ and $\mathrm{PO} 4^{3-}$ treatment. When the salt content is $0 \%$, the COD removal efficiency of the system reaches $98.47 \%, \mathrm{COD}=$ $30 \mathrm{mg} / \mathrm{L}$. When the salt content increased by 1\%, 2\%, COD efficiency decreased slightly to 98.04 and $97.29 \%$, the COD content was 39.5 respectively; $56 \mathrm{mg} / \mathrm{L}$. Similarly, for NH4 + and PO43treatment performance, when the salt content is $0 \%, \mathrm{NH}^{4+}$ and $\mathrm{PO}^{3-}$ treatment efficiency is $95.41 \% ; 88.54 \%, \mathrm{NH}^{4+}=7.8 \mathrm{mg} / \mathrm{L}, \mathrm{PO}^{3-}=3.6 \mathrm{mg} / \mathrm{L}$. When the salt content was increased by $1 \%$ and $2 \%$, the $\mathrm{NH}^{4+}$ treatment efficiency was decreased to 94.82 and $94.97 \%$, respectively and the $\mathrm{PO}^{3-}$ treatment efficiency was decreased to 85.58 and $78.1 \%$, respectively. It can be seen that, with salt content less than $2 \%$, there is not much change in the processing efficiency of the system. When the salt content is $3 \%$, the efficiency of treatment decreases markedly and does not meet the output standard according to QCVN11-MT: 2015 / BTNMT (column B) COD is 150 $\mathrm{mg} / \mathrm{L}, \mathrm{NH}^{4+}=54 \mathrm{mg} / \mathrm{L}, \mathrm{PO}^{3-}=34 \mathrm{mg} / \mathrm{L}$.

Thus, the treatment efficiency of activated sludge anaerobic combining aerobic system was significantly affected when the salt content of seafood processing wastewater is greater than $3 \%$. High salinity can cause high osmotic stress or the inhibition of the reaction pathways in the organic degradation process. This results in a significant decrease in biological treatment efficiency. In addition, high salt content induces cell lysis, which causes increased effluent solids. The 
populations of protozoa and filamentous organisms required for proper flocculation were also significantly reduced by the elevated salt content ${ }^{13-17}$. Therefore, high salinity in fish processing wastewater will lead to difficulties in biological treatment processes ${ }^{13}$. High salinity is generally known to cause plasmolysis and loss of cell activity ${ }^{18,19}$.

\subsection{Effect of the retention time (HRT) to efficiency}

From the research results we understand the effect of salt content on the processing efficiency of the system when the salt content of $3 \%$ affects the processing efficiency of the system. Therefore, when the effect of retention times in anaerobic tank were 16 hours, 24 hours and retention times in an aerobic tank were 6 hours and 8 hours for processing efficiency ${ }^{20,21}$, we conducted two contents salt as $0 \%$ and $3 \%$, respectively.
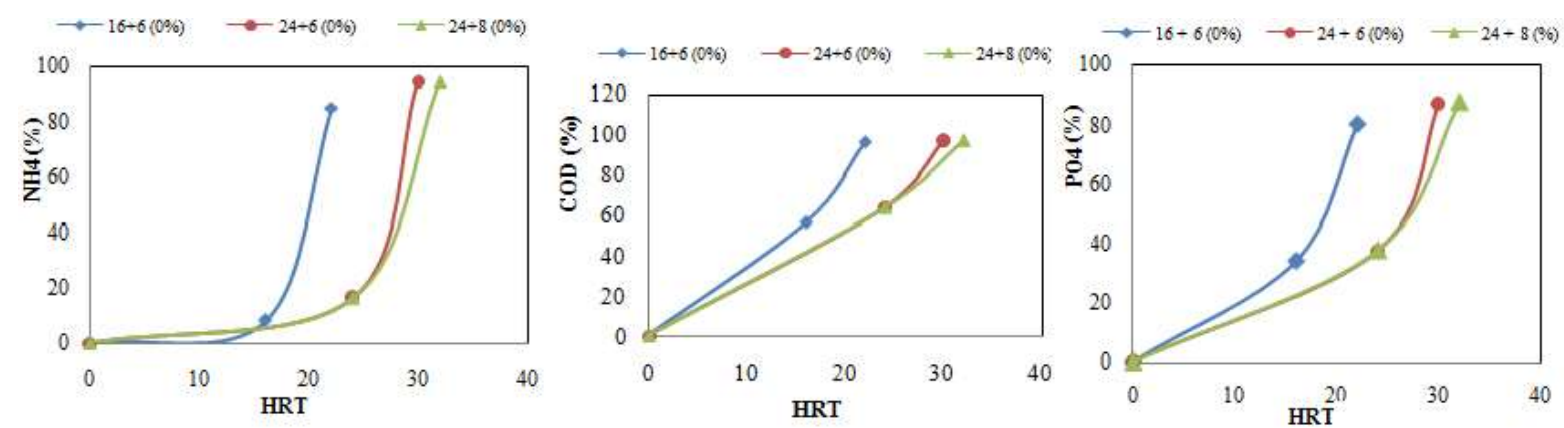

Fig 4. Effect of the retention time (HRT) to efficiency $\mathrm{COD}, \mathrm{NH}^{4+}$ and $\mathrm{PO}^{3-}$ at salt concentration $0 \%$

For $0 \%$ salt concentration, changing the retention time from 22 hours to 32 hours, in which anaerobic retention time is 16 hours and 24 hours, aerobic retention time is 6 hours, 8 hours shows the treatment performance $\mathrm{COD}, \mathrm{NH}^{4+}$ and $\mathrm{PO}^{3-}$ management increases when increasing anaerobic process retention time. However, keeping the anaerobic retention time to 24 hours, changing aerobic retention time to be 6 hours and 8 hours, the experimental results have shown that the treatment efficiency increased not much. In general, the processing efficiency of the whole process for 30 hour and 32 hour retention times was nearly equal. Thus, the anaerobic retention time of 16 hours can be selected without prolonging up to 24 hours, the aerobic retention time is 6 hours, the system can still handle well the output standards.
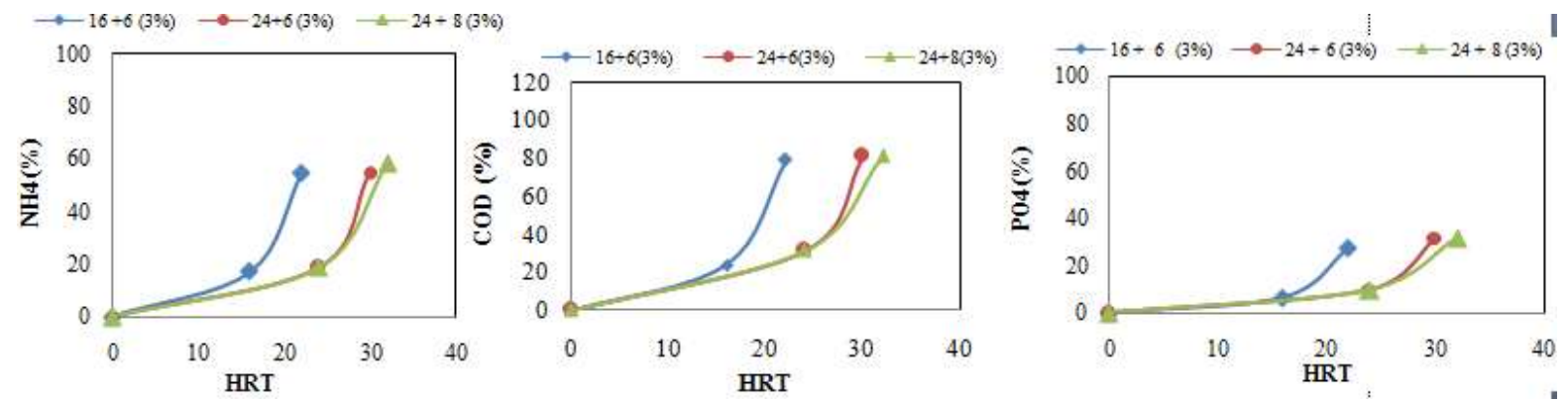

Fig 5. Effect of the retention time (HRT) to efficiency $\mathrm{COD}, \mathrm{NH}^{4+}$ and $\mathrm{PO}^{3-}$ at salt concentration $3 \%$

For $3 \%$ salt concentration, the treatment efficiency is much lower than the $0 \%$ salt content. The anaerobic process performance is reduced by more than half, from over $60 \%$ to $30 \%$. Processing efficiency of the whole process ranges from about $97 \%$ to about $80 \%$. When the anaerobic retention time is 24 hours, the aerobic storage time is 8 hours, the processing efficiency does not increase much compared with the anaerobic retention time of 16 hours, when the aerobic storage 
time is 6 hours. Thus, through the graphs showing the processing efficiency of COD, $\mathrm{NH}^{4+}$ and $\mathrm{PO}^{3}$ with surveyed retention times, retention time can be selected during anaerobic process to be 16 hours, retention time in the aerobic process to be 6 hours is suitable for seafood processing wastewater treatment system.

\subsection{Effect of the activated sludge content to efficiency}

Several reports have indicated the adverse effects of high salinity or shocks of $\mathrm{NaCl}$ on organic removal efficiency and sludge settle ability ${ }^{22,23}$. In the treatment system with biological treatment process, activated sludge plays an important role in determining the treatment efficiency of pollutants and shortening the processing time. The experiment was conducted when the active sludge content in anaerobic tank was fixed to $8000 \mathrm{mg} / \mathrm{L}$ and changed the activated sludge content in aerobic tank with values of $4000 \mathrm{mg} / \mathrm{L}, 6000 \mathrm{mg} / \mathrm{L}$ and $8000 \mathrm{mg} / \mathrm{L}$. The retention time of anaerobic period is 16 hours, the aerobic time is 6 hours in (Fig. 6).
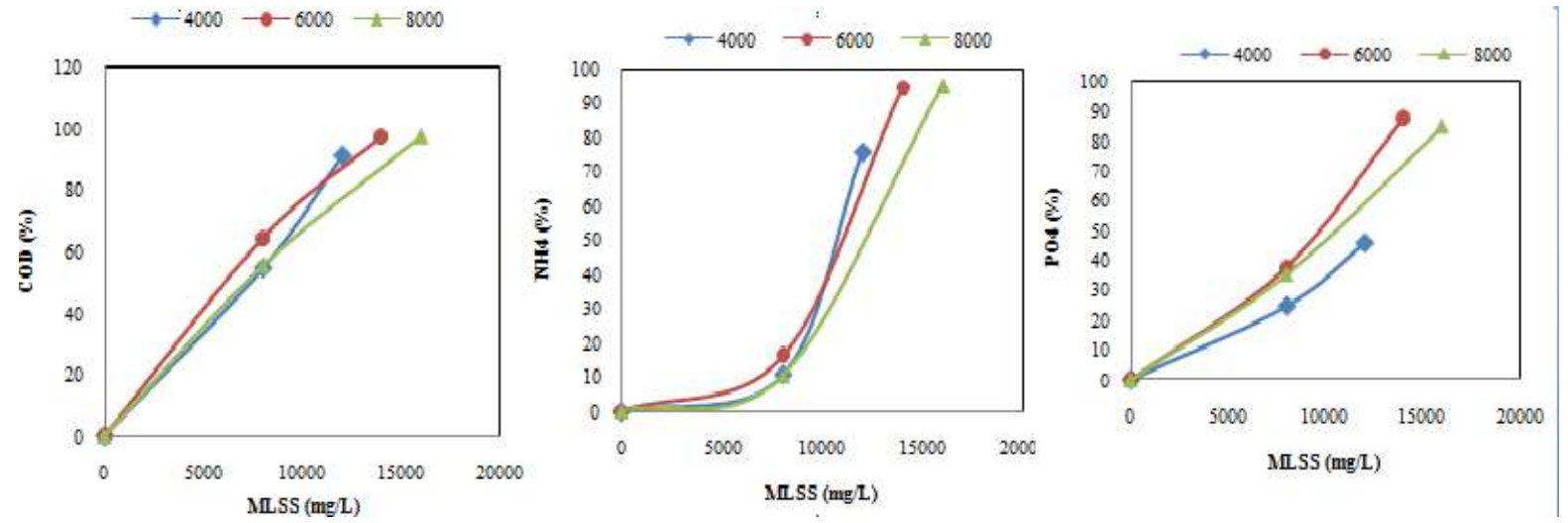

Fig 6. Effect of the activated sludge content to efficiency $\mathrm{COD}, \mathrm{NH}^{4+}$ and $\mathrm{PO}^{3-}$

In Fig. 6, with activated sludge content of $4000 \mathrm{mg} / \mathrm{L}$, the processing efficiency of COD, $\mathrm{NH}^{4+}$ and $\mathrm{PO}^{3-}$ the whole process is $91.25 \% ; 75.83 \% ; 45.63 \%$, the output value is $168 \mathrm{mg} / \mathrm{L}, 36.5$ $\mathrm{mg} / \mathrm{L}$, respectively and $27.3 \mathrm{mg} / \mathrm{L}$ has not met the output standard. With activated sludge content of $6000 \mathrm{mg} / \mathrm{L}$, the processing efficiency of COD, $\mathrm{NH}^{4+}$ and $\mathrm{PO}^{3-}$ the whole process is $97.32 \%$; $94.54 \% ; 87.56 \%$, output values are $54 \mathrm{mg} / \mathrm{L}, 7.1 \mathrm{mg} / \mathrm{L}$ and $4.2 \mathrm{mg} / \mathrm{L}$. The treatment efficiency is higher than the activated sludge content of $4000 \mathrm{mg} / \mathrm{L}$. Output parameter values have reached the output standard. When increasing activated sludge content to $8000 \mathrm{mg} / \mathrm{L}, \mathrm{COD}$ and $\mathrm{NH}^{4+}$ treatment efficiency increased to $97.42 \%$ and $95.03 \%$. In general, the higher the mud content, the better the performance. However, the activated sludge content of $6000 \mathrm{mg} / \mathrm{L}$ and $8000 \mathrm{mg} / \mathrm{L}$ has no significant difference in treatment performance. Thus, the sludge content of $6000 \mathrm{mg} / \mathrm{L}$ in aerobic tank is suitable for treatment because if the activated sludge is too high, then handling the excess sludge is also a problem.

\subsection{Study on supplementation of saline microorganisms to improve processing efficiency}

Salt concentrations above $2 \%(20 \mathrm{~g} / \mathrm{L} \mathrm{NaCl})$ in the wastewater will affect the growth of the bacteria. Study from Joong et al. ${ }^{24}$ in the experiment for examination of the salt effect on cellular growth shows that there was no effect on cellular growth at concentrations of $1 \%$ and $2 \% \mathrm{NaCl}$, but they observed that there was an effect on cellular growth at the concentration of $3.5 \% \mathrm{NaCl}$. Burnett ${ }^{22}$ reported that operation of activated sludge process at salt contents higher than $20 \mathrm{~g} / \mathrm{L}$ was characterized by poor flocculation, high effluent solids, and a severe decrease in substrate utilization rate. Hamoda and Al$A \operatorname{ttar}^{25}$ reported on the effect of standard sodium chloride on aerobic activated sludge treatment 
processes. They demonstrated that no decrease in wastewater treatment performance was observed at concentrations approaching 3\% $\mathrm{NaCl}(\mathrm{w} / \mathrm{w})$. The saline microorganism of Bacillus velezensis was isolated from the sea of the Institute of Natural Products Chemistry. Surveying the concentration of microorganisms favoring salinity from $3-10 \%$ (density of microbial cells equivalents to $10^{4}$ $\mathrm{CFU} / \mathrm{mL}$ ) added to the wastewater treatment process had a salinity level of $3 \%$. The result is given in Fig. 7 as follows:

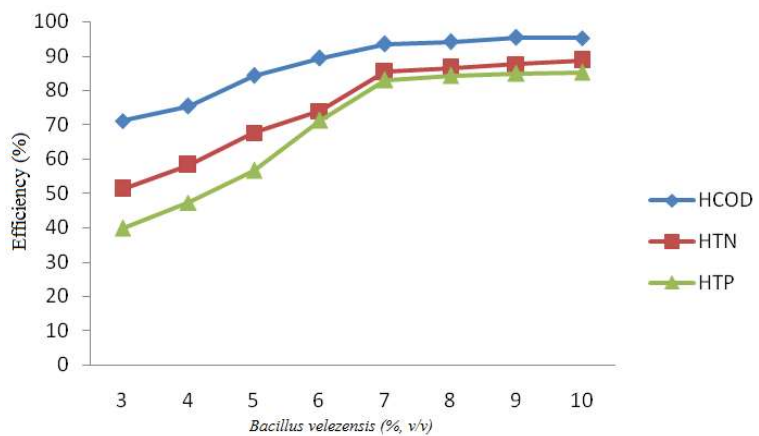

Fig. 7. Effect of ration Bacillus velezensis additional to processing efficiency

The results show that treatment efficiency was directly proportional to increasing microbial concentration. However, at a high rate of supplementation (7-10\%), treatment efficiency increased but not significantly. The reason is that the nutrients in the environment are exhausted. The appropriate percentage of additional microorganisms for treatment is determined at $7 \%$. The quality of wastewater after treatment with anaerobic activated sludge combining aerobic with additional saline microorganisms the output standard according to QCVN 11-MT: 2015 / BTNMT (column B). However, as the concentration of salinity exceeds this limit, the tendency of bacteria aggregation or adsorption decreases ${ }^{26,27}$.
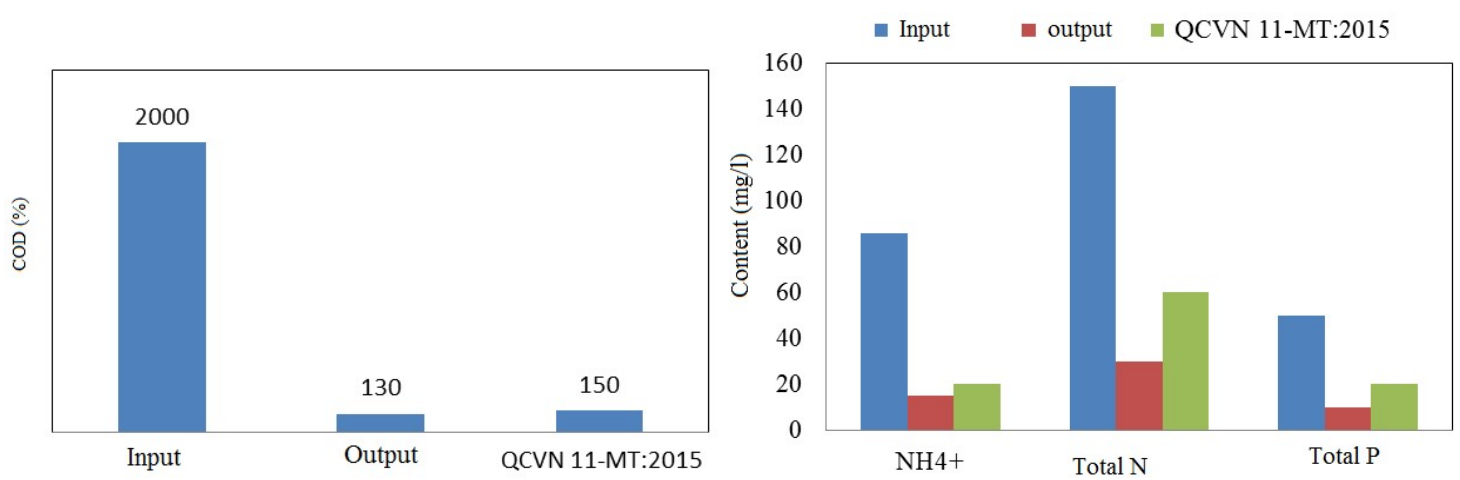

Fig. 8. The quality of waste water after treatment with anaerobic activated sludge system combining aerobic with added saline microorganisms

\section{Conclusions}

The results of this study have been useful for determining the optimum operational conditions for seafood processing wastewater treatment by method biological. The biological continuous flow system should minimize the amounts of pollutants in the effluent water to reduce environmental contaminant levels and to improve the seafood processing effluent water quality so that it could be reused and protect the environment quality.

\section{Acknowledgement}

The paper has been completed with the financial support of Ministry of Industry and Trade 
(Vietnam), ĐTKH.072/18.

\section{Experimental section}

\section{Material and methods}

\subsection{Seafood processing wastewater preparation}

The major types of wastes found in seafood-processing wastewaters are blood, offal products, viscera, fins, fish heads, shells, skins, and meat "fines". These wastes contribute significantly to the suspended solids concentration of the waste stream. However, most of the solids can be removed from the wastewater and collected for animal food applications. Wastewaters from the production of fish meal, solubles, and oil from herring, menhaden. However, the degree of pollution of a wastewater depends on several parameters. The most important factors are the types of operation being carried out and the type of seafood being processed.

Fish processing wastewater and fish blood were collected from the processing of edible fish species, which were purchased from a local fish market. The processing of fish involves handskinning, filleting, and washing with tap water. The fish processing wash water and fish blood were collected immediately in a beaker and homogenized by agitation on the stirrer plate for 30 min. The wastewater was then kept in a polyethylene bottle and subsequently stored in the freezer below $0^{0} \mathrm{C}$ for future use. To make the influent for feeding into the bioreactor, the raw wastewater was diluted with distilled water to achieve the required concentration. The wastewater from seafood processing with the chemical input parameters of $\mathrm{pH}=7-8.5, \mathrm{COD}=2000 \mathrm{mg} / \mathrm{L}$, total nitrate nitrogen $=150 \mathrm{mg} / \mathrm{L}, \mathrm{NH} 4+=90 \mathrm{mg} / \mathrm{L}$, total phosphorus $=50 \mathrm{mg} / \mathrm{L}^{8,9}$ and at different salt concentrations $(0.5 \%, 1.0 \%, 1.5 \%, 2.0 \%, 3.0 \%, 4.0 \%, 4.5 \%, 5.0 \% \mathrm{w} / \mathrm{v} \mathrm{NaCl})$ and without salt content $(0.0 \% \mathrm{w} / \mathrm{v} \mathrm{NaCl})^{11,12}$. The wastewater used as feed was maintained in a refrigerator at $4{ }^{0} \mathrm{C}$. It was maintained in a feed reservoir and mixing was applied manually at regular intervals.

\subsection{Biological treatment}

The biological treatment was applied to the seafood processing wastewater after sedimentation/flotation and coagulation/flocculation steps in order to evaluate the organic matter removal efficiency by activated sludge. The experiments for this study were performed in a biological system that consists of a $7.5 \mathrm{~L}$ feed tank containing the wastewater to be treated, an anaerobic and an aeration tank, height $(\mathrm{H}) 30,5 \mathrm{~cm}$, edge $15.5 \mathrm{~cm}$ working volume (V) $5 \mathrm{~L}$.

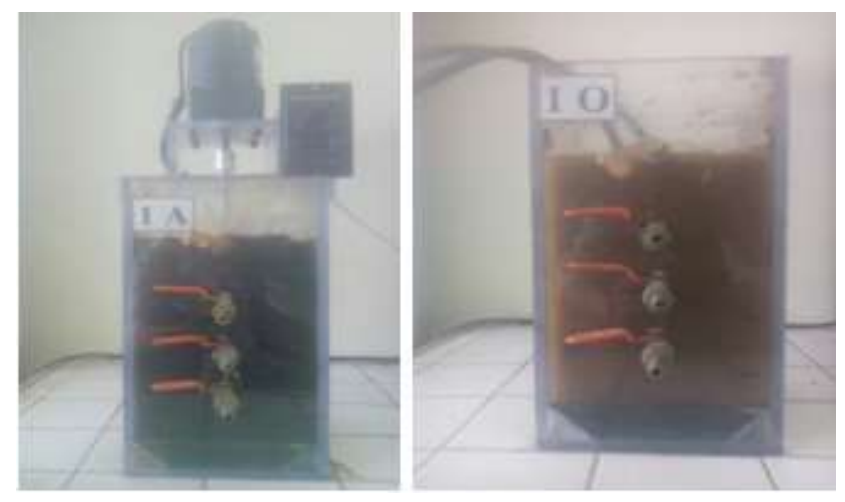

Fig 9. Anaerobic tanks and SBR used in the study 


\subsection{Activated Sludge Systems}

In an activated sludge treatment system, an acclimatized, mixed, biological growth of microorganisms (sludge) interacts with organic materials in the wastewater in the presence of excess dissolved oxygen and nutrients (nitrogen and phosphorus). The microorganisms convert the soluble organic compounds to carbon dioxide and cellular materials.

Most of the activated sludge systems utilized in the seafood-processing industry are of the extended aeration types: that is, they combine long aeration times with low applied organic loadings. The detention times are 1 to 2 days. The suspended solids concentrations are maintained at moderate levels to facilitate treatment of the low-strength wastes, in experiment have used aerobic activated sludge available at the laboratory of Material Technology Center, Institute of Applied Technology, activated sludge is fed by domestic wastewater, has yellow brown color, activated sludge concentration about $6000 \mathrm{mg} / \mathrm{L}$, with the ratio of MLVSS/MLSS $0.7-0.8$. Besides, we have used Anaerobic sludge Obtaining from anaerobic BHT tank at the Institute of Environmental Science and Technology, Hanoi University of Science and Technology. Anaerobic sludge is black, BHT concentration is about 8000 - $10000 \mathrm{mg} / \mathrm{L}$, with MLVSS/MLSS ratio 0.7 0.75 .

\subsection{Analytical methods}

Standard Methods for the Examination of Water and Wastewater were adopted for the measurement in Table $1^{28,29}$.

Table 1. Measurement used for examination of water and wastewater

\begin{tabular}{|c|c|c|}
\hline Parameters & Analytical methods & Equipment and machinery used \\
\hline $\mathrm{pH}$ & TCVN 6492:2011 (ISO 10523:2008) & PH measurement electrode (E01581 Thermo, USA) \\
\hline COD & Standard method $(5220 \mathrm{D})$ & Heating block (DRB200, USA); Photometric machine (Thermo Scienfic, USA) \\
\hline Total Nitrogen & Persulfate Digestion & HACH DR 6000 \\
\hline $\mathrm{NH}_{4}{ }^{+} \mathrm{N}$ & Standard method $\left(4500-\mathrm{NH}_{3}, \mathrm{~F}\right)$ & Ammonium measuring electrode (E01581 Thermo, USA) \\
\hline Total Phosphorus & Molybdovanadate uses TNT pipes & HACH DR6000 \\
\hline DO & $\begin{array}{c}\text { TCVN 6001-2:2008 (ISO 5815- } \\
2: 2003 \text { ) }\end{array}$ & Máy YSI - 5000 (Mỹ) \\
\hline Turbidity & USEPA Method 180.1 & Turbidity meter HI 98703 (Hanna, Italy) \\
\hline SS, MLSS & TCVN 6625:2000 (ISO 11923:1997) & Drying oven (Daihan / Korea), analytical (HR 200, Japan) \\
\hline Salinity & & Salinity and EXTECH temperature meter EC170 \\
\hline
\end{tabular}

The reported values represent the average of at least two measurements; in most cases each sample was injected three times, validation being performed by the apparatus only if the coefficient of variation $(\mathrm{CV})$ was smaller than $5 \%$.

\section{References}

1. Lefebvre, O., \& Moletta, R. (2006). Treatment of organic pollution in industrial saline wastewater: a literature review. Water Res., 40(20), 3671-3682.

2. Li, A., \& Guowei, G. (1993). The treatment of saline wastewater using a two-stage contact oxidation method. Water Sci. and Technol., 28(7), 31-37.

3. Omil, F., Méndez, R. J., \& Lema, J. M. (1995). Characterization of biomass from a pilot plant digester treating saline wastewater.J. Chem. Technol. Biot.: Int. Res. Proc., Environ. Clean Technol., 63(4), 384-392.

4. Hamoda, M. F., \& Al-Attar, I. M. S. (1995). Effects of high sodium chloride concentrations on activated sludge treatment. Water Sci. and Technol., 31(9), 61-72.

5. Kargi, F., \& Uygur, A. (1996). Biological treatment of saline wastewater in an aerated percolator unit utilizing halophilic bacteria. Environ. Technol., 17(3), 325-330.

6. Intrasungkha, N., Keller, J., \& Blackall, L. L. (1999). Biological nutrient removal efficiency in 
treatment of saline wastewater. Water Sci. and Technol., 39(6), 183-190.

7. Henry, J.G., \& Heinke, G.W. (1996). Environmental Science and Engineering. 2nd Ed.; Prentice-Hall, Inc.: Upper Saddle River, NJ, 445-447.

8. Sherly, T. M. V., Harindranathan, N., \& Bright, S. I. S. (2015). Physicochemical analysis of seafood processing effluents in Aroor Gramapanchayath, Kerala. IOSR J. Environ. Sci. Toxicol. Food Technol, 9, 38-44.

9. Carawan, R.E., Chambers, J.V., \& Zall, R.R. (1979). Seafood Water and Wastewater Management, The North Carolina, Agricultural Extension Service. U.S.A.

10.Mosquera-Corral, A., Campos, J. L., Sánchez, M., Méndez, R., \& Lema, J. M. (2003). Combined system for biological removal of nitrogen and carbon from a fish cannery wastewater. J. Environ. Eng., 129(9), 826-833.

11.Hall, G. M., \& Ahmad, N. H. (1997). Surimi and fish-mince products. In Fish processing technology (pp. 74-92). Springer, Boston, MA.

12.COWI. (1999). Industrial Sector Guide. Cleaner Production Assessment in Fish Processing Industry; UNEP DTIE: Paris, France; Danish Environmental Protection Agency: Copenhagen, Denmark, 1999.

13.Méndez, R., Omil, F., Soto, M., \& Lema, J. M. (1992). Pilot plant studies on the anaerobic treatment of different wastewaters from a fish-canning factory. Water Sci. and Technol., 25(1), 37-44.

14.Cui, Y. W., Zhang, H. Y., Ding, J. R., \& Peng, Y. Z. (2016). The effects of salinity on nitrification using halophilic nitrifiers in a Sequencing Batch Reactor treating hypersaline wastewater. Sci. Rep., 6, 24825.

15.Sherly, T. M. V., Harindranathan, N., \& Bright, S. I. S. (2015). Physicochemical analysis of seafood processing effluents in Aroor Gramapanchayath, Kerala. IOSR J. Environ. Sci. Toxicol. Food Technol, 9, 38-44.

16.Woolard, C. R., \& Irvine, R. L. (1995). Response of a periodically operated halophilic biofilm reactor to changes in salt concentration. Water Sci. and Technol., 31(1), 41-50.

17.Stewart, M. J., Ludwig, H. F., \& Kearns, W. H. (1962). Effects of varying salinity on the extended aeration process. J. Water Pollut. Control Fed., 1161-1177.

18.Campos, J. L., Mosquera-Corral, A., Sanchez, M., Méndez, R., \& Lema, J. M. (2002). Nitrification in saline wastewater with high ammonia concentration in an activated sludge unit. Water Res., 36(10), 2555-2560.

19.Rene, E. R., Kim, S. J., \& Park, H. S. (2008). Effect of COD/N ratio and salinity on the performance of sequencing batch reactors. Bioresour. Technol., 99(4), 839-846.

20.Tchobanoglous, G., \& Burton, F. L. (1991). Wastewater engineering treatment, disposal and reuse. McGraw-Hill, Inc.

21.Grady Jr, C. L., Daigger, G. T., Love, N. G., \& Filipe, C. D. (2011). Biological wastewater treatment. CRC press.

22.Burnett, W. E. (1974). The effect of salinity variations on the activated sludge process. Water Sew. Works, 121, 37-38.

23. Oren, A., Gurevich, P., Azachi, M., \& Henis, Y. (1992). Microbial degradation of pollutants at high salt concentrations. Biodegradation, 3(2-3), 387-398.

24.Kim, J. K., Kim, J. B., Cho, K. S., \& Hong, Y. K. (2007). Isolation and identification of microorganisms and their aerobic biodegradation of fish-meal wastewater for liquidfertilization. Int. Biodeterior. Biodegrad., 59(2), 156-165.

25.Hamoda, M. F., \& Al-Attar, I. M. S. (1995). Effects of high sodium chloride concentrations on activated sludge treatment. Water Sci. Technol., 31(9), 61-72.

26.Dincer, A. R., \& Kargi, F. (1999). Salt inhibition of nitrification and denitrification in saline wastewater. Environ.Technol., 20(11), 1147-1153.

27.Jean, D. S., \& Lee, D. J. (1999). Effects of salinity on expression dewatering of waste activated sludge. J. Colloid Interf. Sci., 215(2), 443-445.

28.APHA; AWWA (2005). Standard Methods for Water and Wastewater Examinations, 21 st ed.; American Public Health Association (APHA); American Water Works Association (AWWA): 
Washington, DC, USA.

29.APHA; AWWA. (1995). Standard Methods for the Examination of Water and Wastewater, 19th ed.; American Public Health Association (APHA); American Water Works Association (AWWA); Water Pollution Control Federation (WPCF):Washington, DC, USA.

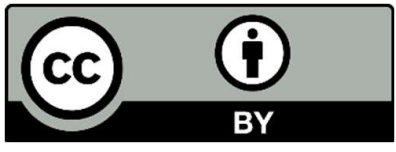

(C) 2020 by the authors; licensee Growing Science, Canada. This is an open access article distributed under the terms and conditions of the Creative Commons Attribution (CC-BY) license (http://creativecommons.org/licenses/by/4.0/). 